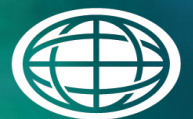

Savannah River

National Laboratory ${ }^{m}$

OPERATED BY SAVANNAH RIVER NUCLEAR SOLUTIONS

\title{
Development of Glass and Glass Ceramic Proppants from Gas Shale Well Drill Cuttings
}

\section{F. C. Johnson}

K. M. Fox

September 2013

SRNL-STI-2013-00431, Revision 0 
SRNL-STI-2013-00431

Revision 0

\section{DISCLAIMER}

This work was prepared under an agreement with and funded by the U.S. Government. Neither the U.S. Government or its employees, nor any of its contractors, subcontractors or their employees, makes any express or implied:

1. warranty or assumes any legal liability for the accuracy, completeness, or for the use or results of such use of any information, product, or process disclosed; or

2. representation that such use or results of such use would not infringe privately owned rights; or

3. endorsement or recommendation of any specifically identified commercial product, process, or service.

Any views and opinions of authors expressed in this work do not necessarily state or reflect those of the United States Government, or its contractors, or subcontractors.

\section{Printed in the United States of America \\ Prepared for \\ U.S. Department of Energy}


SRNL-STI-2013-00431

Revision 0

Keywords: LDRD, Proppants, Flame

Spheroidization

Retention: Permanent

\section{Development of Glass and Glass Ceramic Proppants from Gas Shale Well Drill Cuttings}

F. C. Johnson

K. M. Fox

September 2013

Prepared for the U.S. Department of Energy under contract number DE-AC09-08SR22470.

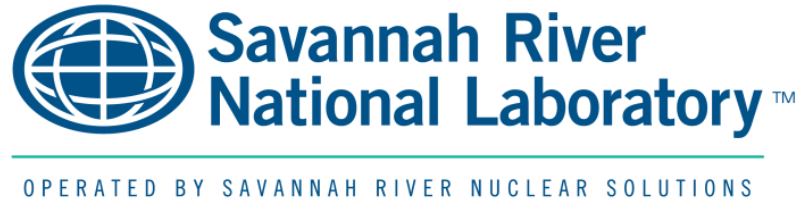




\section{REVIEWS AND APPROVALS}

\section{AUTHORS:}

F. C. Johnson, Process Technology Programs Date

K. M. Fox, Engineering Process Development Date

TECHNICAL REVIEW:

J. W. Amoroso, Process Technology Programs, Reviewed per E7 2.60 Date APPROVAL:

D. R. Click, Manager Date

Process Technology Programs

S.L. Marra, Manager

Date

Environmental \& Chemical Process Technology Research Programs 


\section{ACKNOWLEDGEMENTS}

The authors gratefully acknowledge the guidance and assistance provided by Dr. John Hellmann at The Pennsylvania State University, and Erich Hansen, Jake Amoroso, James Marra, David Missimer, Elise Fox, Whitney Riley, David Best, Henry Ajo, and Phyllis Workman at the Savannah River National Laboratory (SRNL). Funding for this study was provided by the SRNL Laboratory Directed Research and Development program as project LDRD-2013-00007. 


\section{EXECUTIVE SUMMARY}

The objective of this study was to develop a method of converting drill cuttings from gas shale wells into high strength proppants via flame spheroidization and devitrification processing. Conversion of drill cuttings to spherical particles was only possible for small particle sizes $(<53 \mu \mathrm{m})$ using a flame former after a homogenizing melting step. This size limitation is likely to be impractical for application as conventional proppants due to particle packing characteristics. In an attempt to overcome the particle size limitation, sodium and calcium were added to the drill cuttings to act as fluxes during the spheroidization process. However, the flame former remained unable to form spheres from the fluxed material at the relatively large diameters $(0.5-2 \mathrm{~mm})$ targeted for proppants.

For future work, the flame former could be modified to operate at higher temperature or longer residence time in order to produce larger, spherical materials. Post spheroidization heat treatments should be investigated to tailor the final phase assemblage for high strength and sufficient chemical durability. 


\section{TABLE OF CONTENTS}

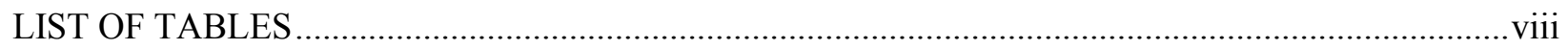

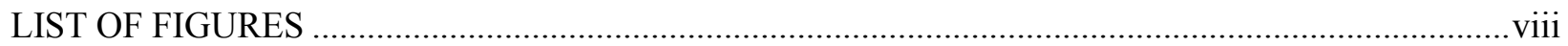

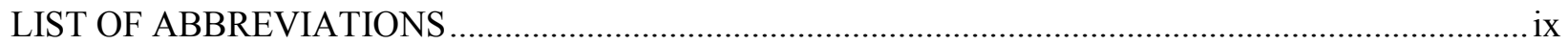

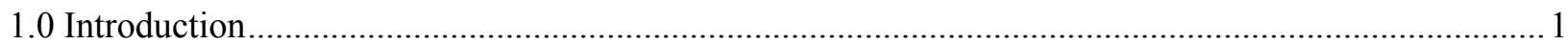

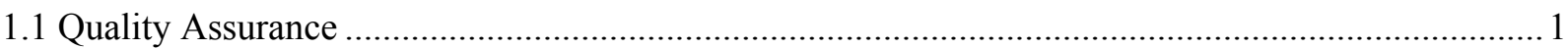

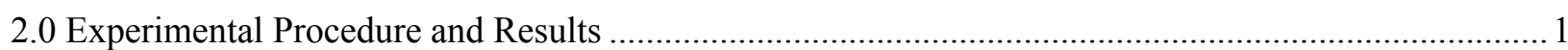

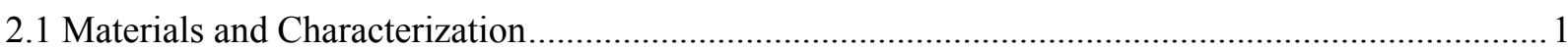

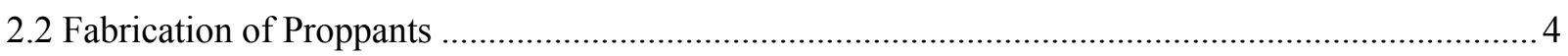

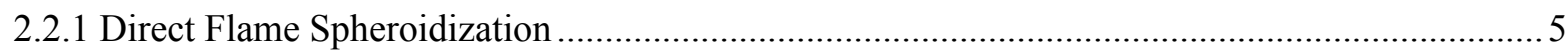

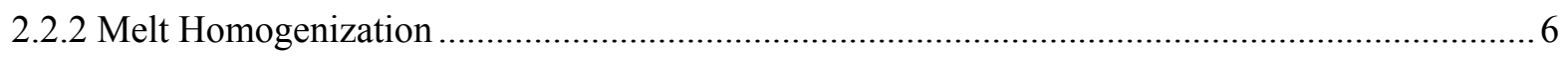

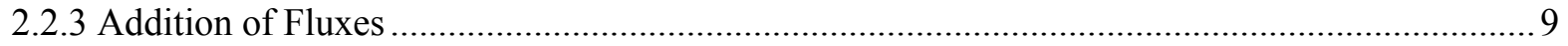

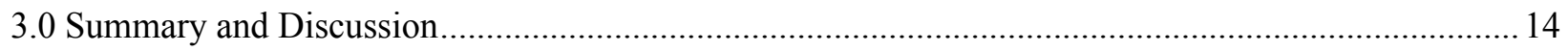

4.0 Future Work 
SRNL-STI-2013-00431

Revision 0

\section{LIST OF TABLES}

Table 2-1. Chemical Composition of the As-Received Drill Cuttings.

Table 2-2. Chemical Composition Comparison of the Drill Cuttings Before and After Melting at $1600{ }^{\circ} \mathrm{C}$

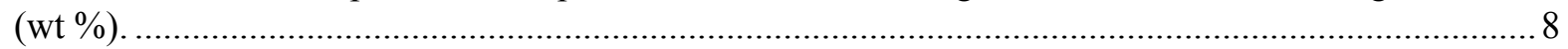

Table 2-3. Targeted Compositions of Drill Cuttings with Fluxes Added (wt \%).................................. 11

Table 2-4. Chemical Composition Comparison of the Drill Cuttings Before and After Melting at $1400{ }^{\circ} \mathrm{C}$ with the Addition of Soda and Lime (wt \%).

\section{LIST OF FIGURES}

Figure 2-1. ILS Cleaned Drill Cuttings Supplied by PSU Unscreened (a) and Screened to -35 Mesh (b).. 2

Figure 2-2. XRD Spectrum and Phase Identification for As-Received Drill Cuttings. ............................ 2

Figure 2-3. Backscattered Electron Micrograph of As-Received, -35 Mesh Drill Cuttings....................... 3

Figure 2-4. Overview of the SRNL Flame Spheroidization System....................................................... 5

Figure 2-5. Backscattered Electron Micrographs of Drill Cuttings Screened to -35 Mesh Prior to (a) and After (b) Processing through the Flame Former............................................................................... 6

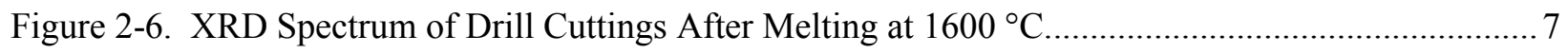

Figure 2-7. Electron Micrographs of Flame Former Products After Melting and Screening to Multiple Size Fractions.

Figure 2-8. Glass Produced by Melting Drill Cuttings with 15 wt $\% \mathrm{Na}_{2} \mathrm{O}$ at $1400{ }^{\circ} \mathrm{C}$. 10

Figure 2-9. Optical Micrographs of Compositions LPT-04 and LPT-Ca30 after Processing Through the Flame Former. 13 


\section{LIST OF ABBREVIATIONS}

$\begin{array}{ll}\text { EDS } & \text { Electron Dispersive Spectroscopy } \\ \text { FT-IR } & \text { Fourier Transform - Infrared Spectroscopy } \\ \text { ICP-OES } & \text { Inductively Coupled Plasma - Optical Emission Spectroscopy } \\ \text { ILS } & \text { Ionic Liquid Separation } \\ \text { MS } & \text { Mass Spectrometer } \\ \text { PSU } & \text { The Pennsylvania State University } \\ \text { SRNL } & \text { Savannah River National Laboratory } \\ \text { TENORM } & \text { Technology Enhanced Naturally Occurring Radioactive Materials } \\ \text { TGA } & \text { Thermal Gravimetric Analysis } \\ \text { XRD } & \text { X-ray Diffraction }\end{array}$




\subsection{Introduction}

Recent advances in directional drilling and hydraulic fracturing have enabled the development of natural gas wells that tap shale resources previously thought to be technically and economically inaccessible. The use of "fracking" is expanding rapidly across the U.S. and other countries. Drilling of natural gas wells creates large quantities of drill cuttings that contain Technology Enhanced Naturally Occurring Radioactive Materials (TENORMs), along with significant quantities of mineral oil. These hazardous components require that cuttings be disposed of in engineered landfills at significant expense. A method to remove the residual oil and to sequester the TENORMs in a fashion that eliminates land-filling would be of significant advantage, both environmentally and economically. Converting these materials into proppants (ceramic particles used for retaining - or propping open - permeable paths in hydrofractured gas and oil wells) offers a unique opportunity to sequester these materials in an environmentally benign manner.

This study combined technologies developed at The Pennsylvania State University (PSU) for Ionic Liquid Separation (ILS) of mineral oils from drill cuttings and advanced processing, characterization, and performance verification of proppant materials with Savannah River National Laboratory's (SRNL) knowledge of melt vitrification, spheroidization of glass and glass-ceramics, and safe, long-term sequestration of radionuclides. The purpose was to develop a transformational manufacturing technology with a high potential to be disruptive in the marketplace.

The objective of this study was to develop a method of converting drill cuttings from gas shale wells, which contain TENORMs, into high strength proppants via flame spheroidization and devitrification processing. Previous research by PSU has shown that proppants can be manufactured from residual mine tailings via pelletization and melt fusion/devitrification processing. ${ }^{1,2}$ These proppants exhibit excellent strength, fracture toughness, crush resistance and long term conductivity, all of which are important prerequisites for acceptance by the well completion industry. PSU has extended the technology from laboratory quantities to pilot scale quantities (tons/day production capacity). Drill cuttings were expected to exhibit chemistries sufficiently similar to mine tailings such that flame spheroidization processes would be directly applicable in a laboratory setting. This study was performed under a Task Technical and Quality Assurance Plan. ${ }^{3}$

\subsection{Quality Assurance}

Requirements for performing reviews of technical reports and the extent of review are established in manual E7 2.60. SRNL documents the extent and type of review using the SRNL Technical Report Design Checklist contained in WSRC-IM-2002-00011, Rev. 2.

\subsection{Experimental Procedure and Results}

\subsection{Materials and Characterization}

Actual drill cuttings from a hydrofractured petrochemical well were supplied for this study by PSU. This material had been cleaned by PSU using their ILS process developed for the removal

\footnotetext{
1 "Engineered Proppants for Hydrofracturing," American Ceramic Society Bulletin, 91 [2] 18-19 (2012).

${ }^{2}$ W. G. Luscher, J. R. Hellmann, B. E. Scheetz, and B. A. Wilson, "Strength Enhancement of Aluminosilicate Aggregate Through Modified Thermal Treatment," Int'l J. Appl. Ceram. Technol., 3 [2] 157-163 (2006).

3 Johnson, F. C., K. M. Fox, and J. C. Marra, "Task Technical and Quality Assurance Plan for the Development of Glass and Glass Ceramic Proppants from Gas Shale Well Drill Cuttings," U.S. Department of Energy Report SRNLRP-2012-00838, Revision 0, Savannah River National Laboratory, Aiken, SC (2012).
} 
of drilling chemicals from the cuttings. The material that was received had been separated into three size fractions: $-16 /+35$ mesh (the size recommended by PSU for proppant fabrication), -35 mesh, and unscreened. Photographs of the material are shown in Figure 2-1. The phase assemblage of the as-received material was characterized via X-ray diffraction (XRD). The resulting XRD spectrum and phase identification are shown in Figure 2-2. The major phase in the material is quartz (based on relative intensities; quantitative analysis was not performed), with minor phases consisting of barite, chlorite-serpentine, muscovite, calcite, and enstatite.

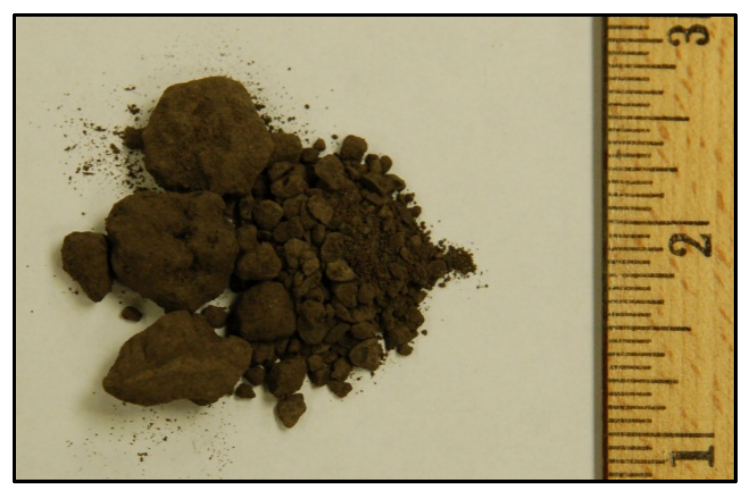

(a)

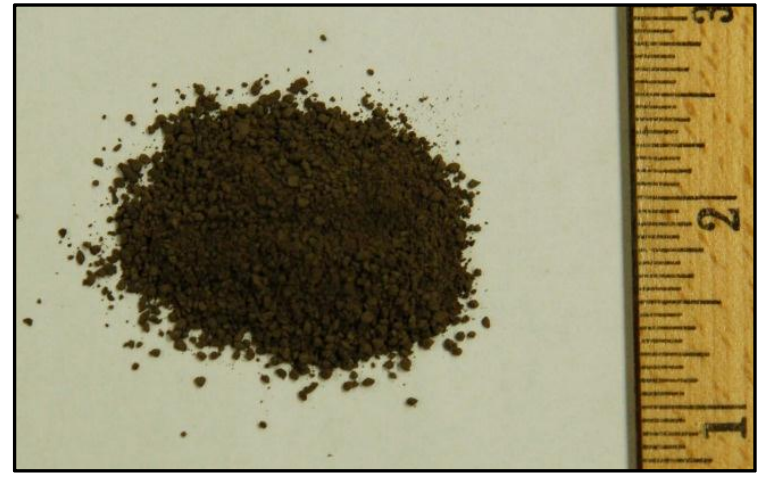

(b)

Figure 2-1. ILS Cleaned Drill Cuttings Supplied by PSU Unscreened (a) and Screened to -35 Mesh (b).

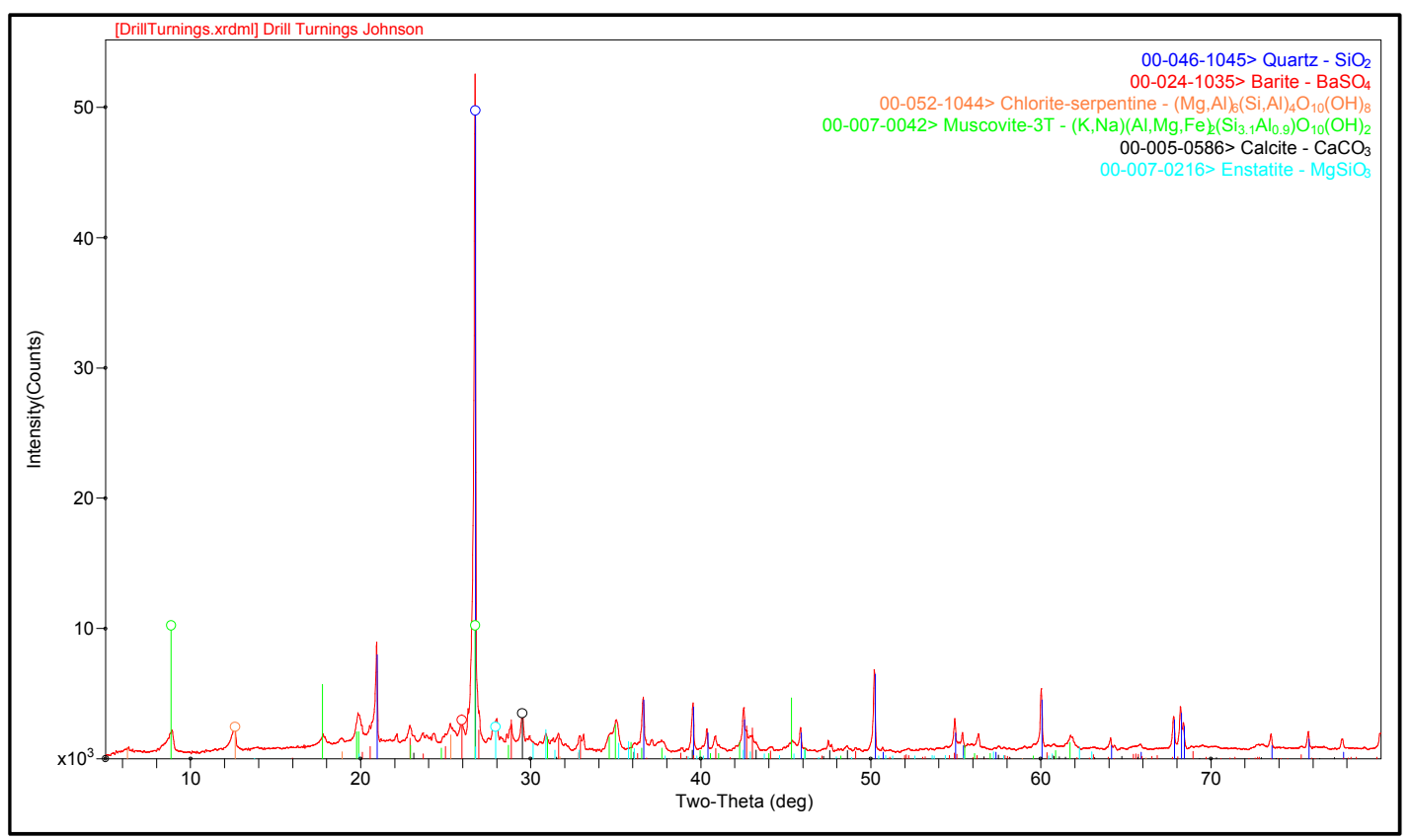

Figure 2-2. XRD Spectrum and Phase Identification for As-Received Drill Cuttings.

Figure 2-3 is a backscattered electron micrograph of the as-received, -35 mesh material. This image shows that the material consisted of a range of particle agglomerate sizes. The backscatter 
image shows the larger atomic weight species as higher intensities (z-contrast); the brighter phase is likely barite based on electron dispersive spectroscopy (EDS) analysis.

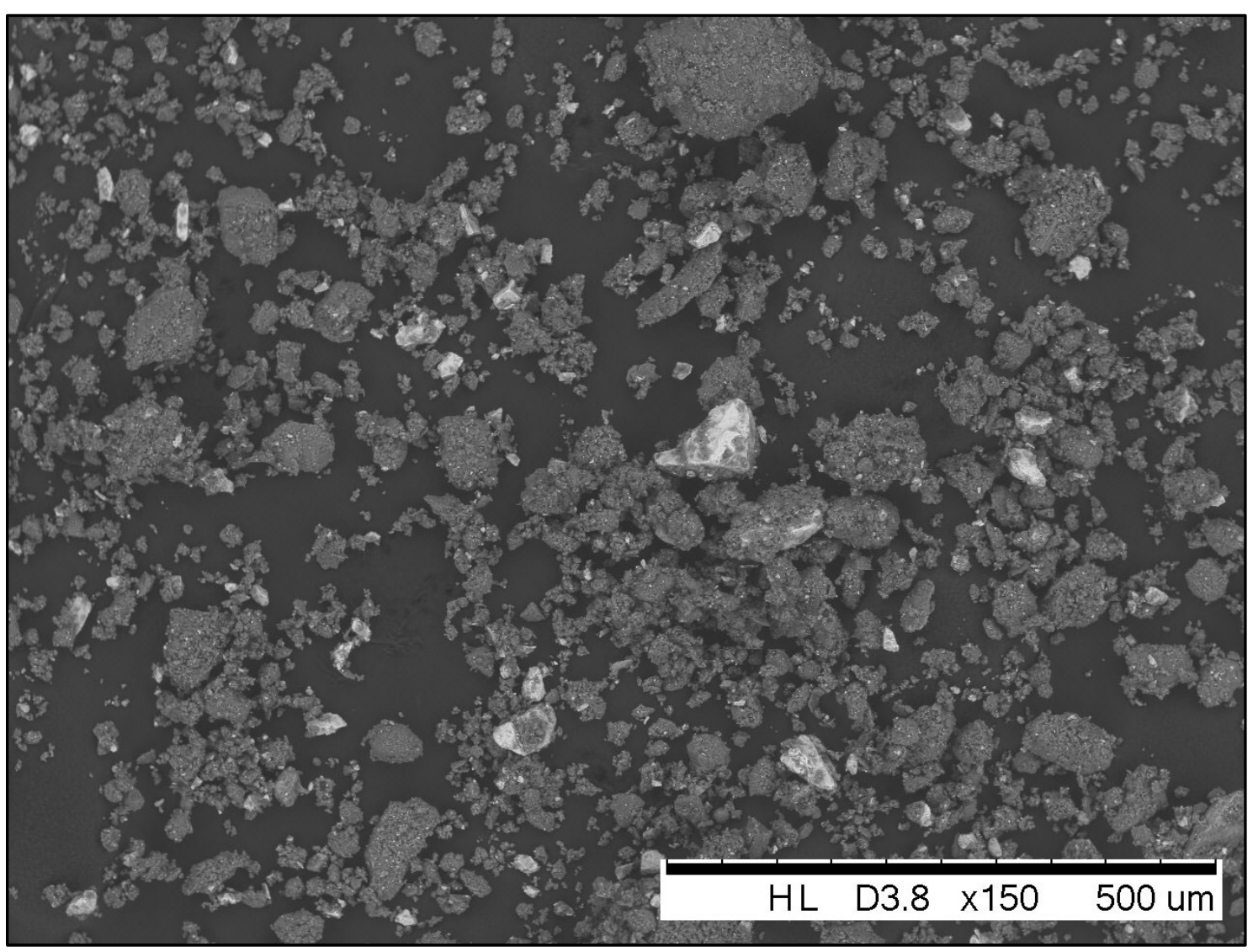

Figure 2-3. Backscattered Electron Micrograph of As-Received, -35 Mesh Drill Cuttings.

Samples of the as-received material were dissolved via peroxide fusion and lithium metaborate fusion, with the resulting solutions analyzed via Inductively Coupled Plasma - Optical Emission Spectroscopy (ICP-OES) to determine chemical composition. The results are presented as oxides in Table 2-1. Note that the total recovery is less than $100 \mathrm{wt} \%$, which is likely due to loss of water in the material, carbonate decomposition, and bitumen decomposition during the dissolution process. 
SRNL-STI-2013-00431

Revision 0

Table 2-1. Chemical Composition of the As-Received Drill Cuttings.

\begin{tabular}{|c|c|}
\hline Component & wt \% \\
\hline $\mathrm{Al}_{2} \mathrm{O}_{3}$ & 13.00 \\
\hline $\mathrm{BaO}$ & 2.15 \\
\hline $\mathrm{CaO}$ & 2.79 \\
\hline $\mathrm{CeO}_{2}$ & 0.02 \\
\hline $\mathrm{Cr}_{2} \mathrm{O}_{3}$ & 0.03 \\
\hline $\mathrm{Cu}_{2} \mathrm{O}$ & 0.02 \\
\hline $\mathrm{Fe}_{2} \mathrm{O}_{3}$ & 5.26 \\
\hline $\mathrm{K}_{2} \mathrm{O}$ & 2.93 \\
\hline $\mathrm{Li}_{2} \mathrm{O}$ & 0.14 \\
\hline $\mathrm{MgO}_{2}$ & 1.34 \\
\hline $\mathrm{MnO}_{2}$ & 0.08 \\
\hline $\mathrm{Na}_{2} \mathrm{O}$ & 1.16 \\
\hline $\mathrm{Nd}_{2} \mathrm{O}_{3}$ & 0.02 \\
\hline $\mathrm{NiO}$ & 0.02 \\
\hline $\mathrm{PbO}_{2}$ & 0.02 \\
\hline $\mathrm{SiO}_{2}$ & 55.26 \\
\hline $\mathrm{SO}_{4}{ }^{2-}$ & 3.44 \\
\hline $\mathrm{SrO}_{\mathrm{TiO}}$ & 0.13 \\
\hline $\mathrm{V}_{2} \mathrm{O}_{5}$ & 0.69 \\
\hline $\mathrm{ZnO}_{2 \mathrm{O} O}$ & 0.03 \\
\hline $\mathrm{ZrO}_{2}$ & 0.02 \\
\hline $\mathrm{Total}$ & 0.03 \\
\hline
\end{tabular}

Based on the XRD and chemical composition data, the drill cuttings were expected to be relatively refractory. That is, the melting temperature of the as-received material would potentially be too high for flame spheroidization using the SRNL equipment. As discussed in the next section, the addition of fluxes was explored to address this issue.

Additional characterization of the drill cuttings included thermal analysis and Fourier Transform - Infrared Spectroscopy (FT-IR). These experiments and their results are discussed more thoroughly in a separate memorandum. ${ }^{4}$ In summary, Thermal Gravimetric Analysis (TGA) showed mass loss occurring in multiple stages, with a total mass loss of approximately $17 \%$ after heating to $1000{ }^{\circ} \mathrm{C}$. A mass spectrometer (MS) connected to the TGA identified the off gas species as a various carbon based compounds including methane and carbon dioxide, as well as sulfur containing species. FT-IR analysis of the material identified various hydrocarbons prior to the TGA cycle. After heating in the TGA-MS, FT-IR analysis showed that the majority of the absorption bands associated with hydrocarbons was no longer present, indicating that decomposition and volatilization of these species occurred upon heating. The decomposition of these species necessitated a more deliberate heat treatment in preparing feed material for flame spheroidization, as will be discussed in the following sections.

\subsection{Fabrication of Proppants}

Three strategies were implemented for forming proppants from the drill cuttings, including:

- Direct flame spheroidization

\footnotetext{
${ }^{4}$ Fox, E. B., "TGA-MS and FT-IR Analysis of Drill Cuttings," Savannah River National Laboratory Memorandum SRNL-L4410-2013-00015, Aiken, SC (2013).
} 
- A homogenizing melt, grinding of the resulting glass (including multiple size fractions), and flame spheroidization

- A homogenizing melt with addition of fluxes, grinding of the resulting glass-ceramic (including multiple size fractions), and flame spheroidization

\subsubsection{Direct Flame Spheroidization}

Direct flame spheroidization was attempted first, as this method requires no homogenizing and therefore would be least expensive for a production scale operation. The SRNL flame former system is described in detail elsewhere. ${ }^{5}$ In summary, the system uses an automated screw feeder that injects the feed powder into an air stream that feeds a propane burner inside a stainless steel vessel. After passing through the burner and flame, the material is quenched by falling through a water spray and collected from an outlet at the bottom of the vessel. A photograph of the system is shown in Figure 2-4.

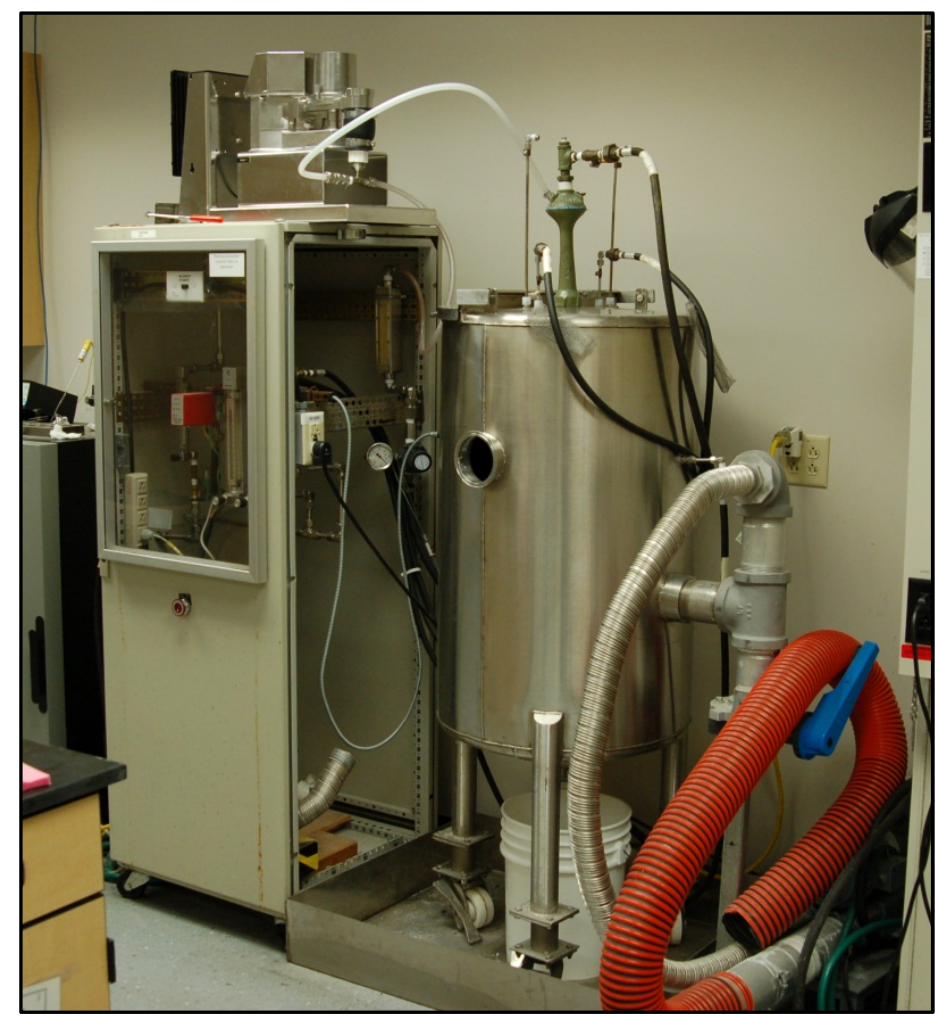

Figure 2-4. Overview of the SRNL Flame Spheroidization System.

The drill cuttings screened to $-16 /+35$ mesh by PSU were run through the flame former first, as this size fraction was recommended for proppants with the desired packed bed flow characteristics. A small quantity of the material (approximately $5 \mathrm{~g}$ ) was fed manually into the flame former and collected after having passed through the flame and quencher. No modification of the material after processing through the flame former was apparent via visual observations (e.g., rounding of particles or change in color), leading to the conclusion that the material was relatively unaffected by the flame spheroidization process. The drill cuttings screened to -35

\footnotetext{
${ }^{5}$ Schumacher, R. F., and E. K. Hansen, "Preparation of Porous-Walled, Hollow Glass Microspheres," U.S. Department of Energy Report WSRC-IM-2006-00020, Revision 0, Savannah River National Laboratory, Aiken, SC (2006).
} 
mesh were next processed through the flame former to determine whether the amount of energy imparted by the flame former would be sufficient with a smaller particle size feed to cause the spheroidization process to commence. Approximately $5 \mathrm{~g}$ of the -35 mesh drill cuttings were manually fed into the flame former and then collected. Micrographs of this material before and after processing through the flame former are shown in Figure 2-5.

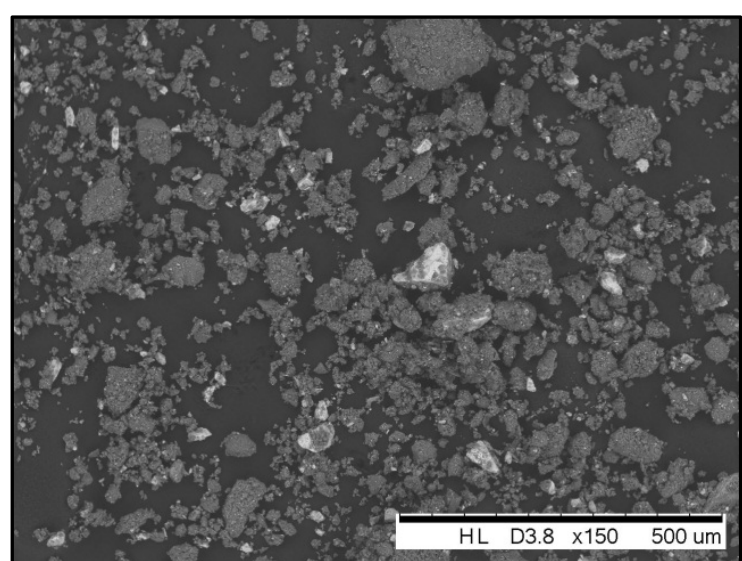

(a)

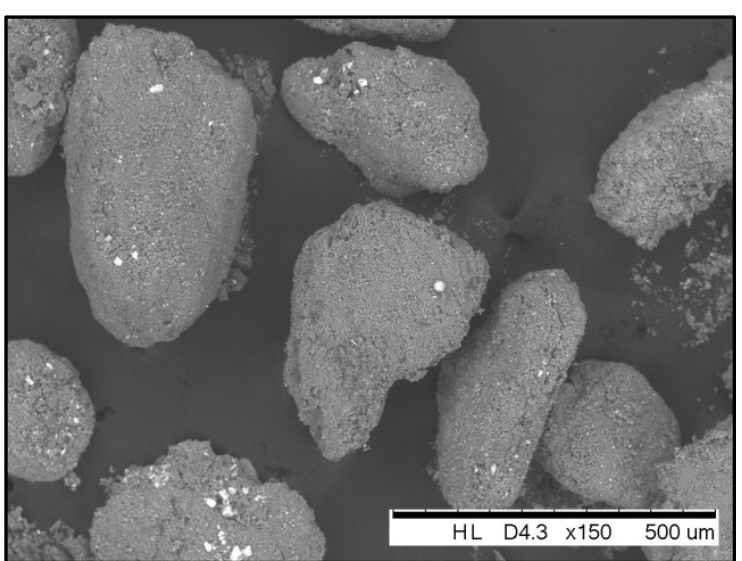

(b)

Figure 2-5. Backscattered Electron Micrographs of Drill Cuttings Screened to -35 Mesh Prior to (a) and After (b) Processing through the Flame Former.

It is apparent from the images in Figure 2-5 that significant agglomeration of the particles occurred when processing the -35 mesh drill cuttings through the flame former. Spheroidization did not occur. Note however that the agglomerates have diameters of roughly $0.5 \mathrm{~mm}$, which is on the order of the size needed for application as proppants. The agglomeration could prove beneficial if a longer residence time or higher temperature in the flame former could spheroidize these larger agglomerates.

\subsubsection{Melt Homogenization}

The next fabrication method incorporated a melting step to homogenize the feed as a glass frit and a grinding step to produce the appropriate size fraction prior to flame spheroidization. Approximately $20 \mathrm{~g}$ of the unscreened drill cuttings were placed in platinum-rhodium alloy crucible for melting in an electrical resistance heated furnace. The material was heated slowly (over a period of $1-2$ hours) though $1200{ }^{\circ} \mathrm{C}$ to allow for decomposition of the hydrocarbons identified via the earlier thermal analysis without ejecting material from the crucible. The temperature of the drill cuttings was raised to $1600{ }^{\circ} \mathrm{C}$ (the maximum operating temperature of the available laboratory furnace) in order to produce a melt, although the viscosity of the material at this temperature was visually observed to be relatively high. The melt could not be poured from the crucible at temperature. These observations reflect the earlier concern that the composition and phase assemblage of the drill cuttings would result in a melting temperature that would make processing impractical.

After melting, the resulting material was characterized via XRD and chemical analysis. The XRD spectrum shown in Figure 2-6 demonstrates that the material was amorphous after melting at $1600{ }^{\circ} \mathrm{C}$. Chemical composition data are given in Table 2-2, with the data for the as-received material included for comparison. Note that the compositions as oxides both before and after melting are normalized to $100 \mathrm{wt} \%$ in this table to support comparisons. In general, sulfur and 
several of the minor components measured in the as-received drill cuttings were below the method detection limit after melting. The iron and sodium concentrations were lower after melting. The most significant change in composition was the decomposition of the hydrocarbons, which is not captured in these analyses but was demonstrated by the TGA-MS and FTIR data described earlier.

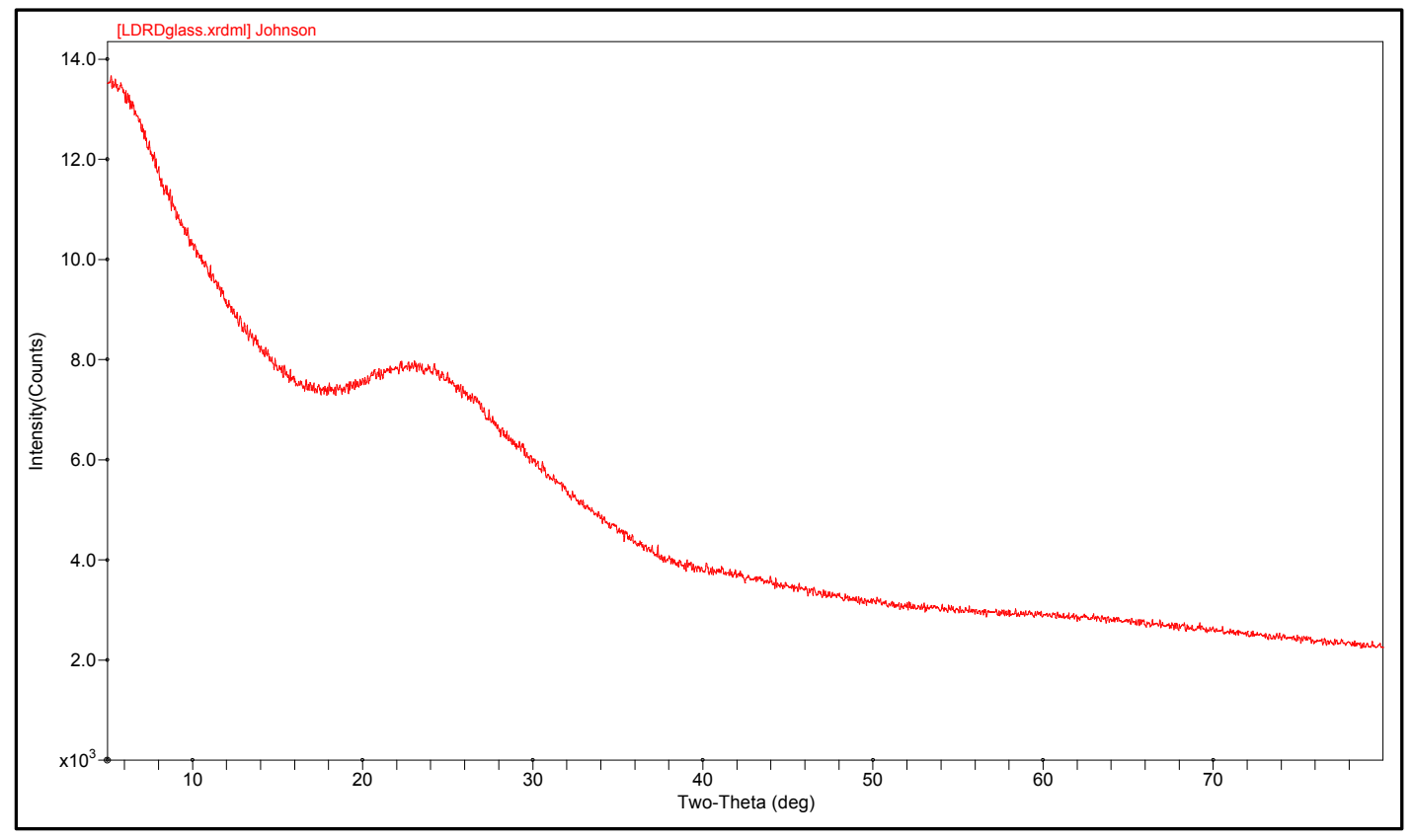

Figure 2-6. XRD Spectrum of Drill Cuttings After Melting at $1600{ }^{\circ} \mathrm{C}$. 
Table 2-2. Chemical Composition Comparison of the Drill Cuttings Before and After Melting at $1600{ }^{\circ} \mathrm{C}(\mathrm{wt} \%)$.

\begin{tabular}{|c|c|c|}
\hline Component & $\begin{array}{c}\text { Drill } \\
\text { Cuttings }\end{array}$ & $\begin{array}{c}\text { Glass from } \\
\mathbf{1 6 0 0} \\
\text { Melt }\end{array}$ \\
\hline $\mathrm{Al}_{2} \mathrm{O}_{3}$ & 14.68 & 15.91 \\
\hline $\mathrm{BaO}$ & 2.43 & 2.71 \\
\hline $\mathrm{CaO}$ & 3.15 & 3.97 \\
\hline $\mathrm{CeO}_{2}$ & 0.02 & BDL \\
\hline $\mathrm{Cr}_{2} \mathrm{O}_{3}$ & 0.03 & BDL \\
\hline $\mathrm{Cu}_{2} \mathrm{O}$ & 0.02 & BDL \\
\hline $\mathrm{Fe}_{2} \mathrm{O}_{3}$ & 5.94 & 5.59 \\
\hline $\mathrm{K}_{2} \mathrm{O}$ & 3.31 & 3.74 \\
\hline $\mathrm{Li}_{2} \mathrm{O}$ & 0.16 & BDL \\
\hline $\mathrm{MgO} \mathrm{MnO}_{2}$ & 1.51 & 1.61 \\
\hline $\mathrm{Na}_{2} \mathrm{O}$ & 0.09 & 0.08 \\
\hline $\mathrm{Nd}_{2} \mathrm{O}_{3}$ & 1.31 & 1.27 \\
\hline $\mathrm{NiO}^{2}$ & 0.02 & BDL \\
\hline $\mathrm{PbO}_{2}$ & 0.02 & BDL \\
\hline $\mathrm{SiO}_{2}$ & 0.02 & BDL \\
\hline $\mathrm{SO}_{4}{ }^{2-}$ & 3.38 & 64.13 \\
\hline $\mathrm{SrO}_{\mathrm{TiO}}$ & 0.15 & BDL \\
\hline $\mathrm{V}_{2} \mathrm{O}_{5}$ & 0.78 & 0.20 \\
\hline $\mathrm{ZnO}_{\mathrm{ZrO}_{2}}$ & 0.03 & 0.79 \\
\hline \hline $\mathrm{BL}_{2} \mathrm{Be}$ & 0.02 & BDL \\
\hline
\end{tabular}

BDL: Below detection limit

After melting, the material was ground to several size fractions, including:

- $-16 /+35$ mesh (0.5 to $1.19 \mathrm{~mm})$

- $-35 /+100$ mesh $(149$ to $500 \mu \mathrm{m})$

- $\quad-100 /+170$ mesh $(88$ to $149 \mu \mathrm{m})$

- $\quad-170 /+270$ mesh $(53$ to $88 \mu \mathrm{m})$

- $\quad-270$ mesh $(<53 \mu \mathrm{m})$

Multiple size fractions were generated to determine a particle size limit for spheroidization using the flame former in its current configuration with the assumption that energy input was the factor limiting the formation of spheres. Material from each size fraction was processed through the flame former. Micrographs of the products are shown in Figure 2-7. Little, if any rounding of the $-16 /+35$ mesh particles occurred. Edge rounding becomes more apparent as the particle size of the feed material is reduced, with spheroids becoming evident in the material screened to $-170 /+270$ mesh. The material screened to -270 mesh resulted in the production of wellformed spheres. While these spheres are likely too small for use as proppants, they prove the concept of converting drill cuttings into spherical particles. Larger energy input to the feed material, either through a longer residence time or higher flame temperature, may be successful in producing larger spheres. 


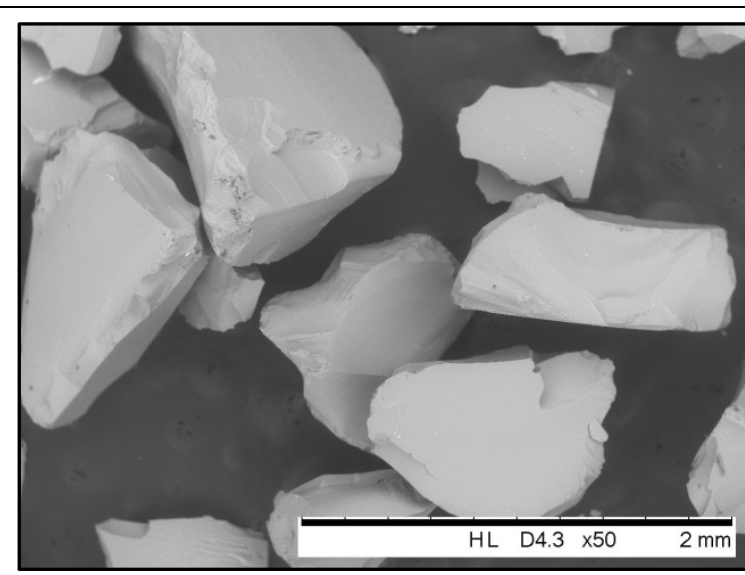

$-16 /+35$ mesh $(0.5$ to $1.19 \mathrm{~mm})$

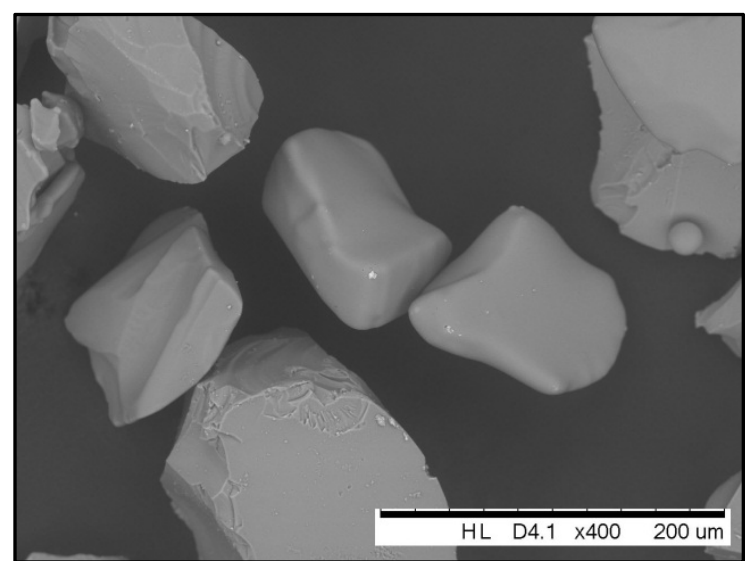

$-100 /+170$ mesh $(88$ to $149 \mu \mathrm{m})$

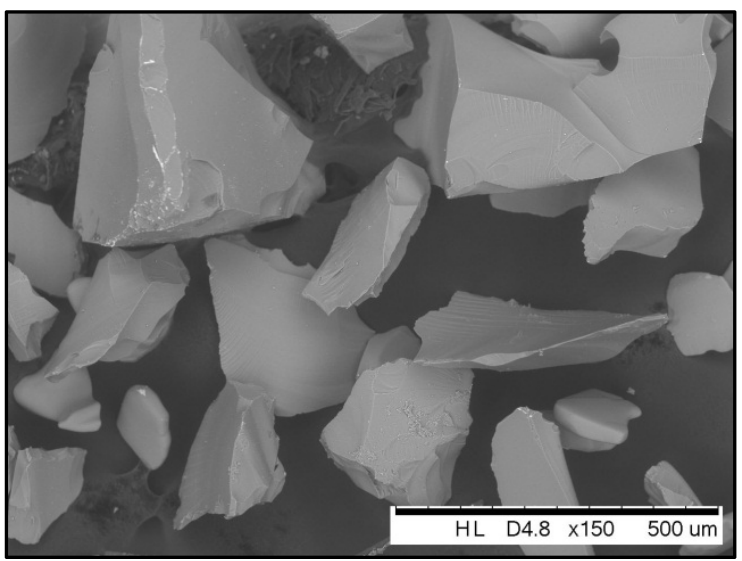

$-35 /+100$ mesh $(149$ to $500 \mu \mathrm{m})$

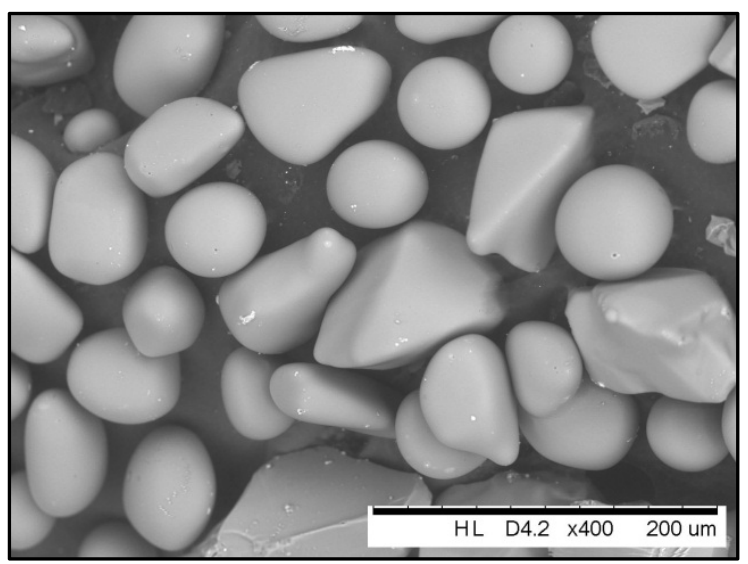

$-170 /+270$ mesh (53 to $88 \mu \mathrm{m})$

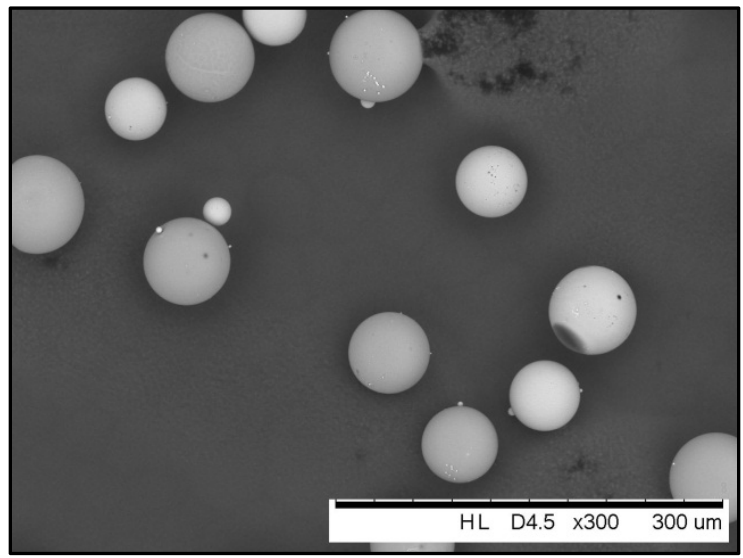

-270 mesh $(<53 \mu \mathrm{m})$

Figure 2-7. Electron Micrographs of Flame Former Products After Melting and Screening to Multiple Size Fractions.

\subsubsection{Addition of Fluxes}

The third fabrication method incorporated the addition of fluxes to the drill cuttings prior to melting. It was hypothesized that other drilling by-products, such as flowback brine solutions, 
might serve as economical sources of material for reducing the melt temperature of the drill cuttings. Limestone is a common flux in the glass industry. A reduced melt temperature may allow for the formation of larger spheres with a lower energy input.

Reagent grade chemicals were used to simulate additions of sodium carbonate $\left(\mathrm{Na}_{2} \mathrm{CO}_{3}\right)$, sodium chloride $(\mathrm{NaCl})$, and limestone $(\mathrm{CaO})$ as fluxes for reducing the melting temperature and viscosity of the drill cuttings. Initial experiments were carried out by adding $\mathrm{Na}_{2} \mathrm{CO}_{3}$ to the drill cuttings at amounts targeting $5,10,15$, and $20 \mathrm{wt} \% \mathrm{Na}_{2} \mathrm{O}$. The material was blended by hand in plastic bags and melted by heating at $8-10{ }^{\circ} \mathrm{C}$ per minute to $1200{ }^{\circ} \mathrm{C}$ to allow for the decomposition of hydrocarbons and carbonate. The crucibles were then placed into a separate furnace (with higher temperature capability) at $1400{ }^{\circ} \mathrm{C}$ for 30 minutes. The crucibles were removed from the furnace and air quenched. The glasses targeting 5 and $10 \mathrm{wt} \% \mathrm{Na}_{2} \mathrm{O}$ contained a large volume of bubbles, indicating that the viscosity of the material remained relatively high at $1400{ }^{\circ} \mathrm{C}$. The glass targeting $15 \mathrm{wt} \% \mathrm{Na}_{2} \mathrm{O}$ was black and shiny, as shown in Figure 2-8. The glass targeting $20 \mathrm{wt} \% \mathrm{Na}_{2} \mathrm{O}$ foamed out of the crucible, which may have been caused by excessive carbonate volatilization. The surface of this glass also had a visible white salt layer. Therefore, a targeted concentration of $15 \mathrm{wt} \% \mathrm{Na}_{2} \mathrm{O}$ appeared to be largest practical (i.e., greatest potential for viscosity reduction) without excessive foaming.

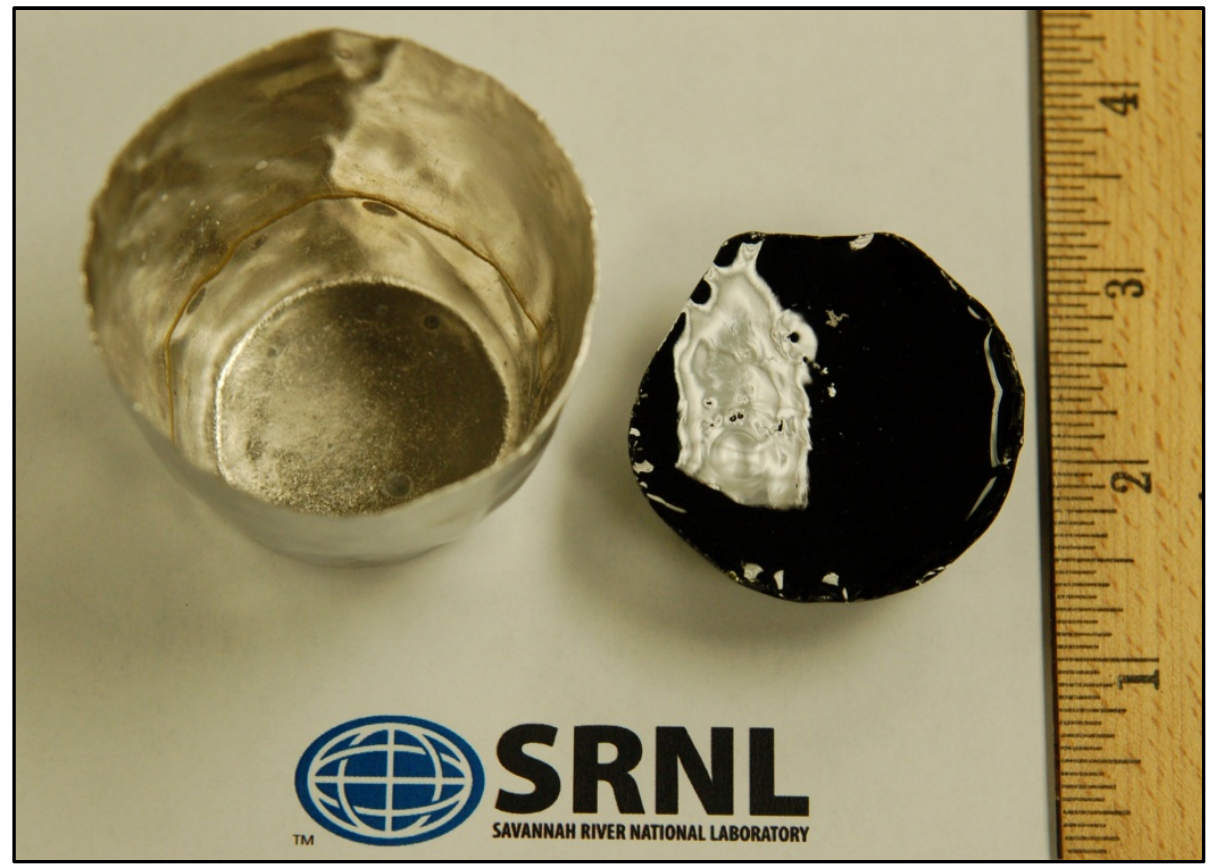

Figure 2-8. Glass Produced by Melting Drill Cuttings with 15 wt $\% \mathrm{Na}_{2} \mathrm{O}$ at $1400{ }^{\circ} \mathrm{C}$.

Next, a melt was attempted targeting the addition of $15 \mathrm{wt} \% \mathrm{Na}_{2} \mathrm{O}$ to the drill cuttings with $\mathrm{NaCl}$ used as a sodium source, rather than $\mathrm{Na}_{2} \mathrm{CO}_{3}$, since sodium in the flowback brine solutions is likely to be in the chloride form. This composition, when melted as described above, resulted in excessive foaming. Therefore, $\mathrm{Na}_{2} \mathrm{CO}_{3}$ was used for the remainder of the laboratory experiments. 
Flowback brines contain several other components in addition to sodium. ${ }^{6}$ It was hypothesized that some of these components would add further benefit in terms of fluxing the drill cuttings melt. Therefore, calcium and magnesium were added, along with sodium, as shown in Table 2-3. An additional composition with a large amount of calcium was fabricated to simulate the addition of limestone, also shown in Table 2-3.

Table 2-3. Targeted Compositions of Drill Cuttings with Fluxes Added (wt \%).

\begin{tabular}{||c|c|c|c|c||}
\hline Identifier & Drill Cuttings & $\mathbf{N a}_{2} \mathbf{O}$ & $\mathbf{C a O}$ & $\mathbf{M g O}$ \\
\hline LPT-01 & 85.0 & 15.0 & 0.0 & 0.0 \\
\hline LPT-02 & 82.5 & 17.5 & 0.0 & 0.0 \\
\hline LPT-03 & 89.4 & 10.0 & 0.5 & 0.1 \\
\hline LPT-04 & 86.9 & 12.5 & 0.5 & 0.1 \\
\hline LPT-Ca30 & 70.0 & 0.0 & 30.0 & 0.0 \\
\hline
\end{tabular}

The compositions shown in Table 2-3 were melted as described earlier in this section. LPT-01 produced excessive foaming. LPT-02 produced a glass that appeared homogeneous, although salts were visible on the surface. LPT-03 remained too viscous at $1400{ }^{\circ} \mathrm{C}$ (many bubbles remained after cooling), while LPT-04 produced a black and shiny glass with no visible salts. LPT-Ca30 produced a glass that appeared homogeneous, although salts were visible on the surface.

Glasses LPT-04 and LPT-Ca30 appeared the most promising based on visual observations. These glasses were dissolved for chemical analysis, and the results are given in Table 2-4. As expected, the glasses are similar in composition to the original drill cuttings with the exceptions of the components added as fluxes. Note that sulfate appears to have been retained in the LPT-Ca30 composition, perhaps as the salt that was visible on the surface of this glass.

\footnotetext{
${ }^{6}$ Haluszczak, L. O., A. W. Rose, and L. R. Kump, "Geochemical Evaluation of Flowback Brine from Marcellus Gas Wells in Pennsylvania, USA,” Applied Geochemistry, 28 55-61 (2013)
} 
Table 2-4. Chemical Composition Comparison of the Drill Cuttings Before and After Melting at $1400{ }^{\circ} \mathrm{C}$ with the Addition of Soda and Lime (wt \%).

\begin{tabular}{|c|c|c|c|}
\hline Component & $\begin{array}{c}\text { Drill } \\
\text { Cuttings }\end{array}$ & LPT-04A & LPT-Ca30 \\
\hline $\mathrm{Al}_{2} \mathrm{O}_{3}$ & 14.68 & 13.48 & 9.68 \\
\hline $\mathrm{BaO}$ & 2.43 & 1.95 & 3.57 \\
\hline $\mathrm{CaO}$ & 3.15 & 3.23 & 36.35 \\
\hline $\mathrm{CeO}_{2}$ & 0.02 & BDL & $\mathrm{BDL}$ \\
\hline $\mathrm{Cr}_{2} \mathrm{O}_{3}$ & 0.03 & $\mathrm{BDL}$ & BDL \\
\hline $\mathrm{Cu}_{2} \mathrm{O}$ & 0.02 & BDL & $\mathrm{BDL}$ \\
\hline $\mathrm{Fe}_{2} \mathrm{O}_{3}$ & 5.94 & 4.28 & 4.22 \\
\hline $\mathrm{K}_{2} \mathrm{O}$ & 3.31 & 2.70 & 1.34 \\
\hline $\mathrm{Li}_{2} \mathrm{O}$ & 0.16 & BDL & BDL \\
\hline $\mathrm{MgO}$ & 1.51 & 1.41 & 1.18 \\
\hline $\mathrm{MnO}_{2}$ & 0.09 & 0.10 & 0.08 \\
\hline $\mathrm{Na}_{2} \mathrm{O}$ & 1.31 & 15.52 & 0.91 \\
\hline $\mathrm{Nd}_{2} \mathrm{O}_{3}$ & 0.02 & 0.02 & BDL \\
\hline $\mathrm{NiO}$ & 0.02 & BDL & BDL \\
\hline $\mathrm{PbO}_{2}$ & 0.02 & $\mathrm{BDL}$ & BDL \\
\hline $\mathrm{SiO}_{2}$ & 62.38 & 56.11 & 39.67 \\
\hline $\mathrm{SO}_{4}^{2-}$ & 3.88 & 0.36 & 2.23 \\
\hline $\mathrm{SrO}$ & 0.15 & 0.13 & 0.30 \\
\hline $\mathrm{TiO}_{2}$ & 0.78 & 0.69 & 0.47 \\
\hline $\mathrm{V}_{2} \mathrm{O}_{5}$ & 0.03 & 0.03 & $\mathrm{BDL}$ \\
\hline $\mathrm{ZnO}$ & 0.02 & BDL & $\mathrm{BDL}$ \\
\hline $\mathrm{ZrO}_{2}$ & 0.03 & BDL & BDL \\
\hline
\end{tabular}

BDL: Below detection limit

Glasses LPT-04 and LPT-Ca30 were ground and screened to $-16 /+35$ and -35 mesh in preparation for processing through the flame former. Optical micrographs of the material after processing through the flame former are shown in Figure 2-9. In all cases, little if any edge rounding has occurred and spheres were not observed. It is apparent that despite the addition of fluxes, the flame former remains unable to impart enough energy into the material at this size to form spheres. Either a smaller particle size or a reconfiguration of the flame former is needed to spheroidize these materials. 

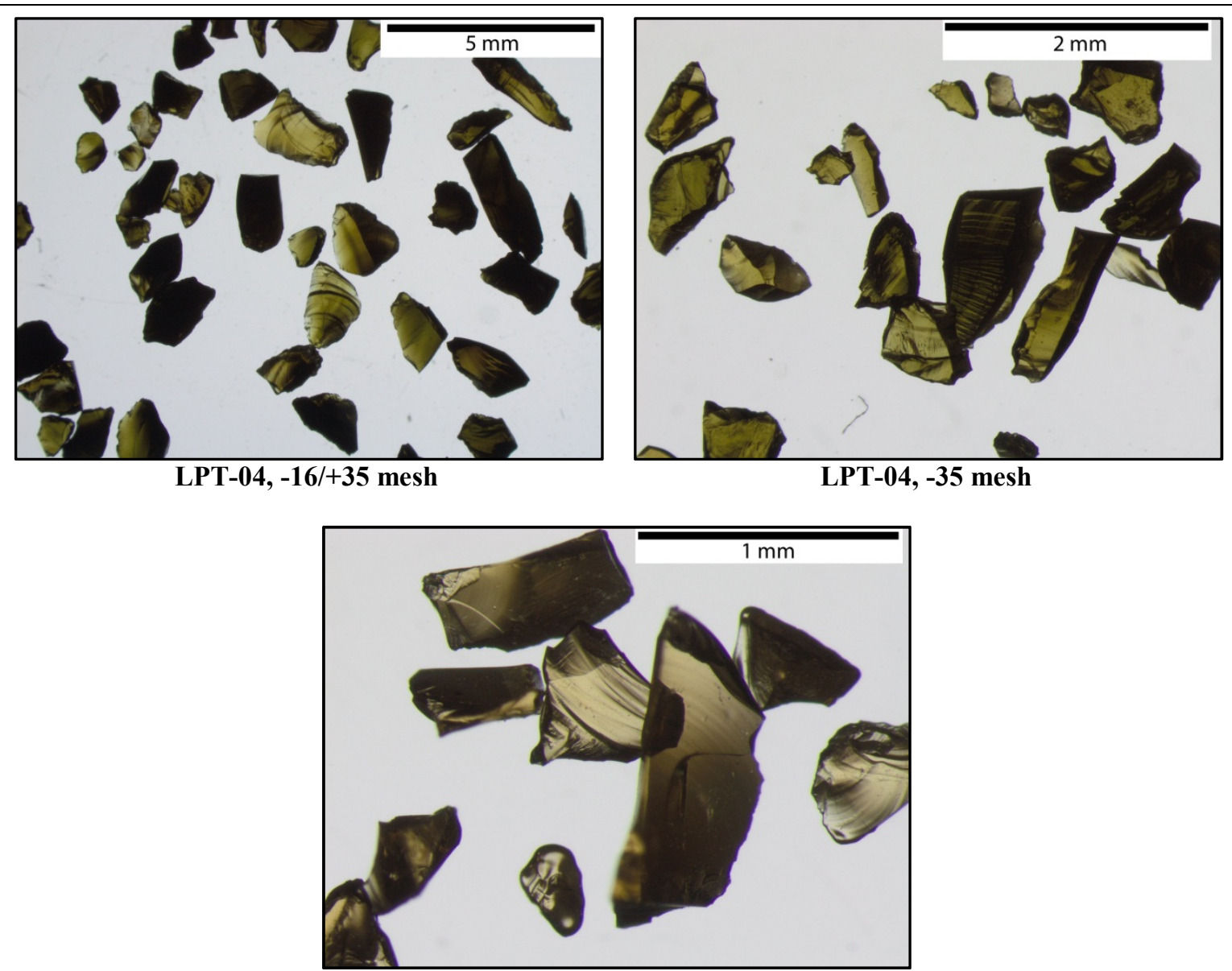

LPT-Ca30, -35 mesh

Figure 2-9. Optical Micrographs of Compositions LPT-04 and LPT-Ca30 after Processing Through the Flame Former. 


\subsection{Summary and Discussion}

The objective of this study was to develop a method of converting drill cuttings from gas shale wells into high strength proppants via flame spheroidization and devitrification processing. Conversion of drill cuttings to spherical particles was only possible at small particle sizes after a homogenizing melting step using the flame former as currently configured. These small sizes are likely to be impractical for application as proppants. Sodium and calcium were added to the drill cuttings as fluxes in an attempt to overcome the particle size limitation. However, the flame former remained unable to form spheres from the fluxed material at the relatively large diameters $(0.5-2 \mathrm{~mm})$ targeted for proppants. It is likely that an increase in residence time or flame temperature would be beneficial in producing larger, spherical particles, as evidenced by the success in producing spheres with a smaller sized feed.

\subsection{Future Work}

The SRNL flame former could be modified to operate at higher temperature or longer residence time in order to produce larger, spherical materials. Post spheroidization heat treatments should be investigated to tailor the final phase assemblage for high strength and sufficient chemical durability. 


\section{Distribution:}

J. W. Amoroso, 999-W

T. B. Brown, 773-A

D. R. Click, 999-W

S. D. Fink, 773-A

E. B. Fox, 999-2W

K. M. Fox, 999-W

E. K. Hansen, 999-W

C. C. Herman, 773-A

E. N. Hoffman, 999-W

F. C. Johnson, 999-W

S. L. Marra, 773-A

J. C. Marra, 999-2W

F. M. Pennebaker, 773-42A

W. R. Wilmarth, 773-A

Records Administration (EDWS) 